\title{
PENERAPAN PRINSIP TANGGUNG GUGAT DALAM PELAKSANAAN TANGGUNG J AWAB SOSIAL PERUSAHAAN DALAM RANGKA IMPLEMENTASI TRIPLE BOTTOM LINE DI INDONESIA
}

\author{
Misahardi Milamarta \\ Fakultas Hukum Universitas Bhayangkara J akarta \\ E-mail: misa@cbn.net.id
}

\begin{abstract}
The goal of this research is to determine the application of the accountability principle in the implementation of corporate social responsibility within the framework of implementation of triple bottom line in Indonesia. It is a normative legal research using secondary dan primary data. Seconda-ry data obtained through libabry research, while the primary data obtained through indepth interviews. To ensure the data validity is used the criticism source. Data were analyzed using editing analysis style. The results of this study indicate that the application of an accountability principle is not easy. Standard or criteria that must be applied in case relating to the application of an accountability principle should clearly and objectively.
\end{abstract}

Keywords: an accountability principle, corporate social responsibility, triple bottom line.

\begin{abstract}
Abstrak
Penelitian ini bertujuan untuk mengetahui penerapan prinsip tanggung gugat dalam pelaksanaan tanggung jawab sosial perusahaan dalam rangka implementasi triple bottom line di Indonesia. Penelitian ini adalah penelitian hukum normatif yang menggunakan data sekunder dan data primer. Data sekunder diperoleh melalui penelitian pustaka sedangkan data primer diperoleh melalui wawancara mendalam. Untuk menjamin validitas data dilakukan kritik sumber. Data dianalisis dengan menggunakan teknik editing analysis style. Hasil dari penelitian ini menunjukkan bahwa penerapan prinsip tanggung gugat dalam pelaksanaan tanggung jawab sosial perusahaan tidaklah mudah. Standar atau kriteria yang harus diterapkan dalam sebuah kasus yang berkaitan dengan penerapan prinisp tanggung gugat harusnya jelas dan obj ektif.
\end{abstract}

Kata kunci : prinsip tanggung gugat, tanggung jawab sosial perusahaan, triple bottom line.

\section{Pendahuluan}

Tanggung jawab sosial perusahaan atau yang lebih dikenal dengan istilah Corporate Social Responsibility/CSR) mulai banyak dibahas sejak dasawarsa terakhir. Perusahaan, pada mulanya, menganggap etika berbisnis sekedar sebagai pemenuhan standar legal dari segi administrasi dan kepatuhan terhadap aturan dan peraturan internal. ${ }^{1}$ Keadaan tersebut telah mengalami perubahan sekarang. Perhatian terhadap tanggung jawab sosial dan etika bisnis semakin besar dan semakin banyak perusahaan mulai menyadari bahwa keberhasilan perusahaan ha-

W.F. Abbott and R.J. Monsen, "On the Measure-ment of Corporate Social Responsibility", Academy of Management J ournal, Vol. 22, No. 3, 2007, hlm. 501-515. rus dibangun dari penghargaan dan kepercayaan masyarakat. ${ }^{2}$ Perusahaan, saat ini diminta, di tuntut dan didorong untuk memperbaiki cara berusaha berdasarkan tingkah laku etis dan kepatuhan hukum. ${ }^{3}$ Perusahaan juga dituntut agar peka terhadap kebutuhan semua pihak yang berkepentingan dalam kegiatan usahanya. ${ }^{4} \mathrm{Pi}$ hak yang berkepentingan yang dimaksud adalah

\footnotetext{
N. Berg and D. Holtbrugge, "Public Affairs Mana-gement Activities of German Multinational Corporations in India", J ournal of Business Ethics, 30, 2009, hlm. 105-19.

3 L. Paine, "Managing for Organisational Integrity", Harvard Business Review, Vol. 72 No. 2, 2010, hlm. 106-17.

4 A.R. Belal, N.A. Khan, and S.A. Alam, "Industrial Pollution and the Environment in Bangladesh: An Overview", Asian Journal of Environmental Manage-ment, Vol. 6, No. 2, 2008, hlm. 115-24.
} 
mereka yang terkena dampak/mampu mempengaruhi keputusan dan tindakan perusahaan. ${ }^{5}$

Sektor industri atau korporasi skala besar, disatu sisi, telah mampu memberikan kontribusi terhadap pertumbuhan ekonomi nasional, di sisi lain eksploitasi sumber daya alam oleh sektor industri seringkali menyebabkan terjadinya degradasi lingkungan yang parah. ${ }^{6}$ Karakteristik umum korporasi skala besar biasanya beroperasi secara enclave atau terpisah dan melahirkan apa yang disebut perspektif dual society, yaitu tumbuhnya dua karakter ekonomi yang paradoks di dalam satu area. ${ }^{7}$ Ekonomi tumbuh secara modern dan pesat, tetapi masyarakat ekonomi justru berjalan sangat lambat.

Kehidupan ekonomi masyarakat semakin involutif, disertai dengan marginalisasi tenaga kerja lokal. Hal ini terjadi karena basis teknologi tinggi menuntut industri lebih banyak menyerap tenaga kerja terampil dari luar masyarakat setempat, sehingga tenaga kerja lokal yang umumnya memiliki keterampilan rendah menjadi terbuang. Keterpisahan (enclavism) ini yang menyebabkan hubungan industri dengan masyarakat menjadi tidak harmonis dan diwarnai berbagai konflik. ${ }^{8}$

Tanggung jawab sosial perusahaan dapat diartikan sebagai komitmen industri untuk mempertanggungjawabkan dampak operasi dalam dimensi sosial, ekonomi, dan lingkungan (ekologi) serta menjaga agar dampak tersebut menyumbang manfaat kepada masyarakat dan lingkungannya. ${ }^{9}$ Tiga pilar inilah (ekologi, ekonomi dan sosial) yang menjadi dasar bagi pelaksanaan tanggung jawab perusahaan, atau yang dikenal dengan "triple bottom line" atau 3-P (People, Profit, Planet). ${ }^{10}$ Pelaksanaan tanggung

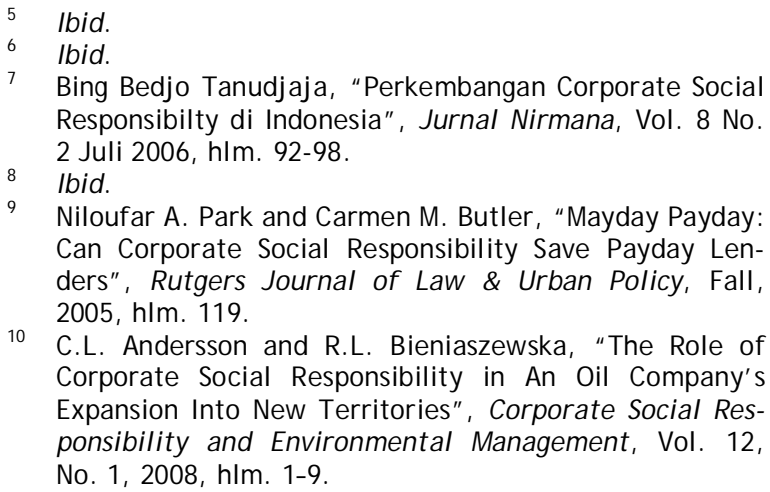
Can Corporate Social Responsibility Save Payday Lenders", Rutgers Journal of Law \& Urban Policy, Fall, 2005, hlm. 119.

10 C.L. Andersson and R.L. Bieniaszewska, "The Role of Corporate Social Responsibility in An Oil Company's Expansion Into New Territories", Corporate Social Responsibility and Environmental Management, Vol. 12, No. 1, 2008, hlm. 1-9.

jawab sosial perusahaan secara konsisten dalam jangka panjang akan membuat masyarakat menerima terhadap kehadiran perusahaan.

Hasil Program Penilaian Peringkat Perusahaan (PROPER) 2004-2005 Kementerian Negara Lingkungan Hidup menunjukkan bahwa dari 466 perusahaan yang dipantau, ada 72 perusahaan mendapat rapor hitam, 150 merah, 221 biru, 23 hijau, dan tidak ada yang berperingkat emas. ${ }^{11}$ Hal ini menunjukkan, bahwa banyak perusahaan tidak menerapkan tanggung jawab lingkungan dan tanggung jawab perusahaan dalam menjalankan bisnis mereka. Tanggung jawab perusahaan dianggap sebagai parasit yang dapat membebani biaya capital maintenance. Dalam hal ini, apabila ada perusahaan yang melaksanakan tanggung jawab perusahaan, itu pun hanya karena adu gengsi.

Suprapto pada tahun 2005 melakukan penelitian terhadap 375 perusahaan di Jakarta, hasil penelitiannya menunjukkan bahwa 166 atau $44,27 \%$ perusahaan menyatakan tidak melakukan kegiatan tanggung jawab sosial perusahaan dan 209 atau 55,75\% perusahaan melakukan kegiatan tanggung jawab sosial perusahaan. Bentuk tanggung jawab sosial perusahaan yang dijalankan meliputi: pertama, kegiatan kekeluargaan (116 perusahaan); kedua, sumbangan pada lembaga agama (50 perusahaan); Ketiga, sumbangan pada yayasan sosial (39) perusahaan); dan keempat, pengembangan komunitas (4 perusahaan). ${ }^{12}$ Survei ini juga mengemukakan, bahwa tanggung jawab sosial yang dilakukan oleh perusahaan sangat tergantung pada keinginan dari pihak manajemen perusahaan sendiri.

Pemerintah Indonesia, melalui UU No. 40 Tahun 2007 tentang Perseroan Terbatas Pasal 74, mewajibkan perusahaan yang bergerak di bidang pengelolaan atau berkaitan dengan sumber daya alam melaksanakan tanggung jawab sosial dan lingkungan, termasuk melaporkan program tanggung jawab sosial tersebut dalam laporan tahunan. Hal ini harus dilakukan dan

11 www.menlh.go.id, diakses tanggal 11 J uni 2011.

12 Suprapto, Siti Adipringadi Adiwoso, "Pola Tanggung Jawab Sosial Perusahaan Lokal di J akarta", Galang, Vol. 1 No. 2, J anuari 2006, hlm. 19-26 
apabila kewajiban ini tidak dilakukan, maka perseroan tersebut akan dikenai sanksi sesuai dengan ketentuan perundang-undangan. Pasal ini menimbulkan perdebatan tentang perlu tidaknya tanggung jawab perusahaan diwajibkan melalui undang-undang, mengingat lemahnya penegakkan hukum di Indonesia secara umum.

Aturan yang lebih tegas mengenai tanggung jawab perusahaan terdapat dalam UU No. 25 Tahun 2007 tentang Penanaman Modal. Ketentuan Pasal 15 huruf $b$ mengatur bahwa setiap penanam modal berkewajiban melaksanakan tanggung jawab sosial perusahaan, apabila tidak dilakukan, maka dapat akan dikenai sanksi mulai dari peringatan tertulis, pembatasan kegiatan usaha, pembekuan kegiatan usaha dan/atau fasilitas penanaman modal, sampai pencabutan kegiatan usaha dan/atau fasilitas penanaman modal.

Kedua ketentuan undang-undang tersebut membuat fobia sejumlah kalangan terutama pelaku usaha lokal, apalagi adanya ketentuan Pasal 74 Undang-undang Perseroan Terbatas yang terdiri dari 4 ayat itu sempat mengundang polemik. Pro dan kontra terhadap ketentuan tersebut masih tetap berlanjut sampai sekarang. Kelompok yang menolak mengajukan argument, bahwa perusahaan adalah organisasi pencari laba dan bukan person atau kumpulan orang seperti halnya dalam organisasi sosial. Perusahaan telah membayar pajak kepada negara dan oleh sebab itu, tanggung jawab perusahaan untuk meningkatkan kesejahteraan publik telah diambil alih pemerintah. ${ }^{13}$ Kelompok yang mendukung, berpendapat bahwa perusahaan tidak dapat dipisahkan dari para individu yang terlibat di dalamnya, yakni pemilik modal dan karyawan. Oleh karena itu, perusahaan tidak boleh hanya memikirkan keuntungan finansial bagi perusahaan saja, melainkan juga harus memiliki kepekaan dan kepedulian terhadap publik, khususnya masyarakat yang tinggal di sekitar perusahaan. Hal ini karena masyarakat adalah sumber dari segala sumber daya yang dimiliki dan

13 Pendapat yang kontra ini dapat pula dilihat pada: P. Bansal and T. Hunter, "Strategic Explanations for the Early Adoption of ISO 14001", J ournal of Business Ethics, Vol. 46, No. 3, 2008, hlm. 289-299. direproduksi oleh perusahaan. Tanpa masyarakat, perusahaan bukan saja tidak akan berarti, melainkan pula tidak akan berfungsi. Tanpa dukungan masyarakat, perusahaan mustahil memiliki pelanggan, pegawai dan sumber produksi lainnya yang berman-faat bagi perusahaan. ${ }^{14}$

Perusahaan, sekalipun telah membayar pajak kepada negara, namun tidak berarti pula perusahaan tidak lagi bertanggung jawab terhadap kesejahteraan publik. Pada negara yang kurang memperhatikan kebijakan sosial (social policy) atau kebijakan kesejahteraan (welfare policy) yang menjamin warganya dengan berbagai pelayanan dan skema jaminan sosial yang merata, manfaat pajak seringkali tidak sampai kepada masyarakat, terutama kelompok miskin dan rentan yang tidak memiliki posisi tawar yang kuat. ${ }^{15}$

\section{Pembahasan \\ Triple Bottom Line sebagai Pilar dari Tang- gung J awab Sosial Perusahaan}

Pendapat yang menyatakan bahwa tujuan ekonomi dan tujuan sosial suatu perusahaan adalah terpisah dan bertentangan adalah pandangan yang keliru. Perusahaan tidak berfungsi secara terpisah dari masyarakat sekitarnya. Faktanya, kemampuan perusahaan untuk bersaing sangat tergantung pada keadaan lokasi di mana perusahaan itu beroperasi. Oleh karena itu, piramida tanggung jawab sosial perusahaan yang dikembangkan Archie B. Carrol harus dipahami sebagai satu kesatuan. Konsep Piramida CSR yang dikembangkan Archie B. Carrol memberi justifikasi teoritis dan logis mengapa sebuah perusahaan perlu menerapkan CSR bagi masyarakat di sekitarnya. Dalam pandangan Carrol, CSR adalah puncak piramida yang erat terkait, dan bahkan identik dengan, tanggungj awab filantropis. Piramida yang dikembangkan Carrol terdiri dari empat tingkatan yaitu: tingkat pertama adalah tanggung jawab ekonomis. Kata kuncinya

\footnotetext{
14 Oliver Krackhardt, "Beyond the Neem Tree Conflict: Questions of Corporate Behaviour in a Globalised World", 21 New Zealand University Law Review 347, une 2005, hlm. 347-355.

$15 \mathrm{~J}$. Crawford, "Responsibility to the International Community As a Whole", 8 Indiana J ournal of Global Legal Studies (INJ GLS), 2007, 303.
} 
adalah make a profit. Motif utama perusahaan adalah mengha-silkan laba. Laba adalah fondasi perusahaan. Perusahaan harus memiliki nilai tambah ekono-mi sebagai prasyarat agar perusahaan dapat terus hidup (survive) dan berkembang. Tingkat kedua adalah tanggung jawab legal. Kata kuncinya adalah obey the law. Perusahaan harus taat hukum. Perusahaan, dalam proses mencari laba, tidak boleh melanggar kebijakan dan hukum yang telah ditetapkan pemerintah. Tingkat ketiga adalah tanggung jawab etis. Perusahaan memiliki kewajiban untuk menjalankan praktek bisnis yang baik, benar, adil dan fair. Norma-norma masyarakat perlu menjadi rujukan bagi perilaku organisasi perusahaan. Kata kuncinya adalah be ethical. Tingkat keempat adalah tanggung jawab filantropis. Selain perusahaan harus memperoleh laba, taat hukum dan berperilaku etis, perusahaan juga dituntut agar dapat memberi kontribusi yang dapat dirasakan secara langsung oleh masyarakat. Tujuannya adalah untuk meningkatkan kualitas kehidupan semua. Kata kuncinya adalah be a good citizen. Para pemilik modal dan pegawai yang bekerja di perusahaan memiliki tanggung jawab ganda, yakni kepada perusahaan dan kepada publik yang kini dikenal dengan istilah non-fiduciary responsibility.

Tanggung jawab sosial perusahaan merupakan kepedulian perusahaan yang didasarkan pada tiga pilar dasar yang dikenal dengan istilah triple bottom lines, yaitu profit, people dan planet (3P). ${ }^{16}$ Triple bottom lines artinya manusia atau faktor sosial, keuntungan atau faktor ekonomi, dan bumi atau faktor lingkungan/ ekologi, tetap dalam keadaan seimbang; keadaan ideal yang diharapkan mendukung pembangunan berkelanjutan. Profit, perusahaan tetap harus berorientasi untuk mencari keuntungan ekonomi yang memungkinkan untuk terus beroperasi dan berkembang. People, perusahaan harus memiliki kepedulian terhadap kesejahteraan manusia. Beberapa perusahaan mengembangkan program tanggung jawab sosial perusahaan

16 C.L. Andersson and R.L. Bieniaszewska, Op.cit. Lihat pula: W. Chapple and J. Moon, 'Corporate Social Responsibility (CSR) in Asia: A Seven Country Study of CSR Web Site Reporting', Business \& Society, Vol. 44, No. 4, 2005, hlm. 415-441. seperti pemberian beasiswa bagi pelajar sekitar perusahaan, pendirian sarana pendidikan dan kesehatan, penguatan kapasitas ekonomi lokal, dan bahkan ada perusahaan yang merancang berbagai skema perlindungan sosial bagi warga setempat. Plannet, bahwa perusahaan peduli terhadap lingkungan hidup dan keberlanjutan keragaman hayati. Beberapa program tang-gung jawab sosial perusahaan yang berpijak pada prinsip ini biasanya berupa penghijauan lingkungan hidup, penyediaan sarana air bersih, perbaikan permukiman, pengembangan pariwisata (ekoturisme). ${ }^{17}$

Tanggung jawab sosial perusahaan yang meliputi faktor profit, people dan planet ini pada dasarnya dimaksudkan untuk: mengutamakan/melindungi kepentingan umum; menganut kebijakan tidak merugikan pihak lain atau "do no harm policies"; melakukan kegiatan secara bertanggung jawab dan bukan sekedar bagi-bagi uang; melebihi persyaratan yang ditetapkan peraturan perundangan (beyond compliance). ${ }^{18}$ Citra perusahaan yang buruk dan sering dimunculkan di media massa jelas tidak mendukung kelancaran operasional perusahaan dan bersifat kontra-produktif terhadap upaya peningkatan produktivitas dan keuntungan.

Perusahaan, saat ini semakin diakui sebagai pelaku bisnis tidak akan bisa terus berkembang jika menutup mata atau tidak peduli dengan situasi dan kondisi lingkungan sosial tempat ia hidup. Penerapan tanggung jawab sosial perusahaan pun harus dipandang sebagai sebuah keharusan. Tanggung jawab sosial perusahaan adalah peran bisnis dan harus menjadi bagian dari kebijakan bisnis. Oleh karena itu, bisnis tidak hanya mengurus permasalahan laba, tetapi juga sebagai sebuah institusi pembelajaran. Bisnis harus mengandung kesadaran sosial terhadap lingkungan sekitar. Terdapat tiga tingkatan motivasi perusahaan melakukan tanggung jawab sosial yaitu: tahap pertama adalah corporate charity, yakni dorongan amal berdasarkan motivasi keagamaan; tahap kedua adalah corpora-

\footnotetext{
17 Loc.cit.

18 Godwin Limberg, dkk, Bukan Hanya Laba Prinsip-prinsip Bagi Perusahaan Untuk Melaksanakan Tanggung Jawab Sosial, Bogor: Center for Forestry Reseach (CIFOR), hlm. 41.
} 
te philantrophy, ${ }^{19}$ yakni dorongan kemanusiaan yang biasanya bersumber dari norma dan etika universal untuk menolong sesama dan memperjuangkan pemerataan sosial. Ide dibelakang corporate philanthropy adalah aliansi antara untuk keuntungan dan bukan untuk keuntungan, di mana modal dapat digunakan untuk keuntungan dari organisasi yang tidak mencari keuntungan. Suatu perusahaan, dengan demikian dapat mengaitkan dirinya pada corporate philanthropy dan tidak bertanggung jawab sosial. Tahap ketiga adalah corporate citizenship, yaitu motivasi kewargaan demi mewujudkan keadilan sosial berdasarkan prinsip keterlibatan sosial.

\section{Penerapan Prinsip Tanggung Gugat dalam Pe- laksanaan Tanggung J awab Sosial Perusahaan sebagai Kewajiban Hukum}

Tanggung jawab sosial perusahaan, secara umum meliputi cara berusaha yang transparan dengan berdasarkan pada nilai-nilai etika, kepatuhan terhadap peraturan dan perundangan dan menghargai, serta menghormati orang lain, masyarakat dan lingkungan. Meskipun terdapat banyak definisi yang berbeda satu dengan yang lain, namun prinsip yang terkan-dung di dalam tanggung jawab sosial perusaha-an adalah sama, yaitu akuntabilitas; transparansi; patuh terhadap peraturan-perundangan, konvensi dan standar internasional; dan menghormati hak asasi manusia. Tulisan ini mengkaji penerapan prinsip tanggung gugat yang berkaitan dengan tanggung jawab sosial perusahaan, termasuk kepatuhan pada aturan. Apa perbedaan antara aturan dan prinsip? Aturan yang tertuang dalam perangkat hukum dikembangkan antara lain untuk mengatur kepentingan umum dan mengatur hubungan yang adil antara para pihak, sedangkan prinsip mengandung unsur norma dan nilai dasar yang digunakan sebagai dasar untuk mengarahkan tindakan. Terdapat pandangan bahwa lebih mudah menerapkan dan menegakkan aturan daripada menerapkan prinsip. Aturan dinilai memberi kejelasan (ada pembatasan yang

19 Stefano Zamagni and Henry Schawalbenberg, "Religious Values and Corporate Decision Making: An Economist's Perspective", Fordham J ournal of Corporate and Financial Law, 2006, hlm. 575-576. jelas) dan ada sanksi apabila terjadi pelanggaran. Prinsip lebih menekankan pada kesadaran dan pengaturan diri. Sebaliknya, akan lebih sulit untuk memantau dan memaksa pihak yang berniat kurang baik mematuhi aturan daripada mengatur pihak yang mendasarkan tindakan pada prinsip-prinsip, karena didasarkan pada kesadaran dan pengaturan dirinya sendiri.

Diskursus mengenai peraturan versus prinsip juga muncul berkaitan dengan penerapan tanggung jawab sosial perusahaan. Beberapa pihak tidak yakin bahwa penerapan tanggung jawab sosial perusahaan oleh perusahaan bisa diserahkan pada kesadaran dan etika bisnis perusahaan tersebut. Mereka lebih mengutamakan penegakan aturan yang berlaku bagi perusahaan untuk melindungi kepentingan umum, sebaliknya, sebagian pihak yang lain berpendapat bahwa akan sulit untuk memantau dan menegakkan semua aturan, sehingga lebih penting untuk menumbuhkan kesadaran agar perusahaan secara sukarela menjalankan tanggung jawab sosialnya. ${ }^{20}$

Saat ini, belum ada kesamaan pandang mengenai konsep dan penerapan tanggung jawab sosial perusahaan, meskipun kalangan dunia usaha menyadari, bahwa tanggung jawab sosial perusahaan sangat penting bagi keberlanjutan usaha suatu perusahaan. Praktek tanggung jawab negara dipercaya menjadi landasan fundamental bagi pembangunan berkelanjutan (sustainnability development), bukan hanya bagi perusahaan, tetapi juga bagi stakeholders dalam arti keseluruhan. Hal tersebut terlihat dari berbagai rumusan mengenai tanggung jawab sosial perusahaan. The World Business Council for Sustainable Development (WBCSD) menyebutkan tanggung jawab perusahaan sebagai: "...continuing commitment by business to behave ethically and contribute to economic development while improving the quality of life of the workforce and their families as whole as of the local community and society at large". J ohn Elkingston's menegaskan:

"Corporate Social Responsibility is a concept that organization especially (but not only) corporations, have an obligation to

20 P. Bansal and T. Hunter, Op.cit. hlm. 289-299. 
consider the interests of customers, employees, shareholders, communities, and ecological considerations in all aspect of their operations. This obligation is been to extend beyond their statutory obligetion to comply with legislation". ${ }^{21}$

Penjelasan Pasal 15 huruf b Undang-undang Penanaman Modal (UUPM) mengatur bahwa yang dimaksud dengan tanggung jawab sosial perusahaan adalah tanggung jawab yang melekat pada setiap perusahaan penanaman modal untuk tetap menciptakan hubungan yang serasi, seimbang, dan sesuai dengan lingkungan, nilai, norma, dan budaya masyarakat setempat. Pasal 1 angka 3 Undang-Undang Perseroan Terbatas (UUPT) mengatur bahwa tangung jawab sosial dan lingkungan adalah komitmen perseroan untuk berperan serta dalam pembangunan ekonomi berkelanjutan guna meningkatkan kualitas kehidupan dan lingkungan yang bermanfaat, baik bagi perseroan sendiri, komunitas setempat maupun masyarakat pada umumnya.

Beberapa pengertian tanggung jawab sosial perusahaan seperti yang telah dipaparkan di atas, belum tampak adanya keseragaman ataupun persamaan persepsi dan cara pandang mengenai tanggung jawab sosial perusahaan. Ketentuan dalam UUPM dan UUPT memiliki titik pandang yang berbeda dalam melihat tanggung jawab sosial perusahaan. UUPM lebih menekankan pada tanggung jawab sosial perusahaan sebagai upaya perusahaan untuk menciptakan harmonisasi dengan lingkungan di mana ia beroperasi, sedangkan UUPT justru mencoba memisahkan antara tanggung jawab sosial dengan tanggung jawab lingkungan. UUPM bertolak dari konsep tanggung jawab perusahaan yang meliputi aspek ekonomi, sosial dan lingkungan (triple bottom line). Namun demikian, keduanya mempunyai tujuan yang sama yaitu mengarah pada tanggung jawab sosial perusahaan sebagai sebuah komitmen perusahaan terhadap pembangunan ekonomi berkelanjutan dalam upayan

21 John Elkington, 2005, Cannibals with Forks, The Triple Bottom Line of Twentieth Century Business, dikutip dari Teguh Sri Pembudi, Corporate Social Responsibility, Sebuah Keharusan dalam Investasi Sosial, Pusat Penyuluhan Sosial (PUSENSOS) Departemen Sosial RI, J akarta: La Tofi Enterprise, 2005, hlm. 19. meningkatkan kualitas kehidupan dan lingkungan.

Berdasarkan berbagai pengertian di atas, maka tanggung jawab sosial perusahaan merupakan komitmen perusahaan terhadap kepentingan para stakeholders dalam arti luas, tidak hanya sekedar kepentingan perusahaan belaka. Dengan kata lain, meskipun secara moral tujuan dari perusahaan maupun penanam modal mengejar keuntungan, bukan berarti perusahaan ataupun penanam modal dibenarkan mencapai keuntungan dengan mengorbankan kepentingankepentingan pihak lain yang terkait. Tanggung jawab sosial sebagai sebuah kewajiban dapat merubah cara pandang maupun perilaku dari pelaku usaha sehingga tanggung jawab sosial tidak hanya dimaknai sebagai sekedar tuntutan moral an-sich, namun juga sebagai kewajiban perusahaan yang harus dilaksanakan. Kesadaran ini memberikan makna bahwa perusahaan bukan lagi sebagai entitas yang mementingkan diri sendiri, alienasi dan/ atau eksklusivitas dari lingkungan masyarakat, melainkan sebuah entitas usaha yang wajib melakukan adaptasi kultural dengan lingkungan sosial. Oleh karena itu, tidak berkelebihan, apabila ke depan tanggung jawab sosial harus dimaknai bukan lagi hanya sekedar responsibility karena bersifat voluntary, tetapi harus dilakukan sebagai mandatory dalam makna liability karena disertai dengan sanksi.

Hukum sebagai produk kebijakan politik tidak selamanya merupakan conditio sine qua non bagi tujuan yang hendak dicapai. Hal ini menunjukkan, bahwa hukum mempunyai batasbatas kemampuan tertentu untuk mengakomodasi nilai-nilai yang tumbuh dan hidup dalam komunitas masyarakat, oleh karena itu Roscoe Pound menyatakan bahwa tugas hukum yang utama dalah social engineering. Doktrin ini mengatakan bahwa hukum harus dikembangkan sesuai dengan perubahan-perubahan nilai sosial. Hukum sebaiknya disusun berdasarkan kepentingan yang ada dalam masyarakat yaitu kepentingan pribadi, masyarakat, dan umum. Hukum, menurut Roscoe Pound, merupakan alat untuk membangun masyarakat (law as a tool of social engineering), sehingga hukum bukan saja berdasarkan pada akal, tetapi juga pengalaman. Akal 
diuji oleh pengalaman dan pengalaman yang dikembangkan oleh akal.

Tanggung jawab sosial perusahaan dalam konteks ini menimbulkan kewajiban bertanggung jawab atas perintah undang-undang dan memperbaiki atau sebaliknya memberi ganti rugi atas kerusakan apa pun yang telah ditimbulkan. Tanggung jawab sosial berada pada ranah moral, sehingga posisinya tidak sama dengan hukum. Moral dalam tanggung jawab sosial lebih mengarah pada tindakan lahiriah yang didasarkan sepenuhnya dari sikap batiniah, sikap inilah yang dikenal dengan "moralitas" yaitu sikap dan perbuatan baik yang betul-betul tanpa pamrih. Tanggung jawab hukum lebih menekankan pada kesesuaian antara sikap lahiriah dengan aturan, meskipun tindakan tersebut secara obyektif tidak salah, barang kali baik dan sesuai dengan pandangan moral, hukum, dan nilai-nilai budaya masyarakat. Namun demikian, kesesuaian saja tidak dapat dijadikan dasar untuk menarik suatu kesimpulan karena tidak tahu motivasi atau maksud yang mendasarinya. ${ }^{22}$

Tanggung jawab sosial, apabila dihubungkan dengan teori tanggung jawab sosial dan aktivitas perusahaan, maka lebih menekankan pada kepedulian perusahaan terhadap kepentingan stakeholders dalam arti luas daripada kepedulian perusahaan terhadap kepentingan perusahaan belaka. Konsep tanggung jawab sosial lebih menekankan pada tanggung jawab perusahaan atas tindakan dan kegiatan usahanya yang berdampak pada orang-orang tertentu, masyarakat dan lingkungan di mana perusahaan melakukan aktivitas usahanya, sehingga tidak berdampak negatif pada pihak-pihak tertentu dalam masyarakat. Hal ini, secara positif mengandung makna bahwa perusahaan harus menjalankan kegiatannya sedemikian rupa sehingga dapat mewujudkan masyarakat yang lebih baik dan sejahtera.

Kondisi di Indonesia masih menghendaki adanya tanggung jawab sosial perusahaan sebagai suatu kewajiban hukum. Kesadaran akan

22 Stefano Zamagni and Henry Schawalbenberg, "Religious Values and Corporate Decision Making: An Economist's Perspective", Fordham Journal of Corporate and Financial Law, 2006, hlm. 575-576. adanya tanggung jawab sosial masih rendah. Hal ini dibuktikan dengan belum adanya kesadaran moral yang cukup dan bahkan seringkali terjadi suatu yang diatur saja masih bisa dilanggar, apalagi apabila tidak diatur. Hal ini disebabkan karena ketaatan orang terhadap hukum masih sangat rendah. Tanggung jawab sosial lahir dari desakan masyarakat atas perilaku perusahaan yang mengabaikan lingkungan dan masyarakat sekitar, seperti: perusakan lingkungan, eksploitasi sumber daya alam, manipulasi pajak, dan menindas buruh. Ditambah lagi, kebanyakan perusahaan juga cenderung membuat jarak dengan masyarakat sekitar. Jika situasi dan kondisi yang terjadi masih seperti ini, maka hukum harus berperan. Tanggung jawab sosial perusahaan yang semula adalah tanggung jawab nonhukum (responsibility) akan berubah menjadi tanggung jawab hukum (liability). Otomatis perusahaan yang tidak memenuhi perundang-undangan dapat diberi sanksi. ${ }^{23}$

Pada dasarnya tanggung jawab sosial perusahaan mengacu pada prinsip-prinsip tata kelola yang baik (good governance), yaitu prinsip akuntabilitas, transparansi, taat hukum, dan partisipasi masyarakat. Prinsip-prinsip tata kelola yang baik tidak hanya berlaku bagi perusahaan, tetapi berlaku bagi semua pihak. Pada tingkat internasional, ada beberapa produk hukum internasional yang dikembangkan untuk mendukung para pihak dalam menerapkan tanggung jawab sosial, seperti global reporting initiative, global compact, UN Conference on Trade and Development. ${ }^{24}$ Instrumen ini disebut code of conduct, yang hanya berisi prinsip-prinsip hukum saja serta bersifat soft law. Prinsip yang terkandung dalam instrumen internasional tersebut meliputi menghargai hak asasi manusia ${ }^{25}$; melindungi hak buruh dan kondisi kerja yang layak; tidak terlibat dalam korupsi; memperhatikan aspek lingkungan hidup dalam beroperasi;

23 Loc. cit.

24 Owen E. Herrnstadt, "Are International Framework Agreements a Path to Corporate Social Responsibility", University of Pennsylvania Journal of Business and Employment Law, Fall 2007, hlm. 187

25 David Monsma, "Equal Rights, Governance, and the Environment: Integrating Environment J ustice Principles in Corporate Social Responsibility", Ecology Law Quarterly, 2006, hlm. 475-478. 
serta bertanggung jawab atas produk dan teknologi yang digunakan. ${ }^{26}$ Selain prinsip, ada pula pengembangan instrumen tanggung jawab sosial perusahaan per sektor industri, misalnya sertifikasi oleh Forest Stewardship Council (FSC) untuk industri perkayuan, Roundtable on Sustainable Palm Oil (RSPO) untuk industri kelapa sawit, Equator Principle untuk sektor perbankan. Pedoman untuk sektor ini lebih terinci, dan biasanya aspek interaksi perusahaan dengan lingkungan sosial dan alam disekitarnya lebih menonjol. ${ }^{27}$

Satu hal yang menarik adalah bahwa seringkali kepatuhan pada hukum dicantumkan sebagai salah satu prinsip tanggung jawab sosial. Kenyataan bahwa diperlukan penegasan seperti ini, menunjukkan bahwa banyak pihak belum bertanggung jawab, karena itu seyogyanya semua pihak harus mematuhi peraturan yang berlaku. Berdasarkan acuan ini dan pengalaman di lapangan dapat diidentifikasi prinsipprinsip yang penting dalam mengembangkan tanggung jawab sosial yaitu mematuhi peraturan yang berlaku, akuntabilitas, transparansi, berperilaku etis (ethical behavior), mengikuti norma dan konvensi internasional; menghargai hak azasi manusia, menghargai dan memperhatikan kepentingan pihak lain, inklusif, melibatkan pihak-pihak dalam pelaksanaan tanggung jawab sosial perusahaan, adaptif dan profesional dalam melaksanakan tanggung jawab sosial perusahaan.

Tanggung gugat mengandung berbagai makna. Tanggung gugat seringkali digunakan sinonim dengan bertanggung jawab, tetapi lebih menekankan kewajiban untuk menjawab/menjelaskan perbuatan, penegakan aturan, dan/ atau siap menerima hukuman atas perbuatan yang salah. Tanggung gugat merupakan salah satu konsep penting dalam diskusi tentang tata kelola yang baik dan berkaitan dengan dunia swasta dan pemerintahan.

26 Surya Deva, "Sustainable Good Governance and Corporation: An Analysis of Asymmetries", Georgetown International Environmental Law Review, Summer 2006, hlm. 735-740.

$27 \mathrm{~J}$. Korhonen, "On the Ethics of Social ResponsibilityConsidering the Paradigm of Industrial Metabolism", J ournal of Business Ethics. Vol. 48, 2008, hlm. 301-315.
Tanggung gugat didefinisikan sebagai $A$ bertanggung gugat terhadap B ketika A wajib untuk menginformasikan kepada $B$ tentang tindakan dan keputusannya (yang lalu atau yang akan datang), menjelaskan alasan/justifikasi dan siap menerima hukuman apabila melanggar. Berkaitan dengan kepemimpinan, tanggung gugat adalah sikap mengakui dan menerima tanggung jawab atas tindakan, produk, keputusan dan kebijakan termasuk administrasi, tata kelola dan implementasi berkaitan dengan peran atau posisi jabatan dan meliputi kewajiban untuk melaporkan, menjelaskan dan bertanggung jawab atas akibat yang timbul.

Pelaksanaan akuntabilitas sering menghadapi beberapa masalah, seperti: perusahaan tidak bertanggung gugat atas operasinya; siapa pihak yang menentukan, apakah perusahaan atau pihak lain, sudah cukup bertanggung gugat? Standar apa yang dipakai?; perusahaan harus bertanggung gugat kepada siapa? Pemegang saham, pemerintah nasional, pemerintah daerah, masyarakat mana?; tidak seimbangnya penerapan prinsip tanggung gugat; mengapa hanya perusahaan yang dituntut bertanggung gugat? apakah pihak lain tidak perlu bertanggung gugat?. Dalam melaksanakan tanggung jawab sosial perusahaan, para pihak harus bertanggung gugat atas rencana, kegiatan, dan dampak tindakan seluruh kegiatannya dengan menggunakan standar dan tolok ukur yang jelas dan menyebarkan informasi secara transparan kepada pihak lain.

Kesulitan yang dihadapi perusahaan dalam penerapan prinsip tanggung gugat meliputi: ${ }^{28}$ Pertama, sebuah perusahaan yang beroperasi di dekat kawasan konservasi diwajibkan berperan serta dalam menjaga kelestarian kawasan konservasi tersebut. Namun pada kenyataan, perusahaan tidak berbuat sesuatu untuk kawasan tersebut, bahkan membiarkan kegiatan perusahaan merusak kawasan. Kendalanya adalah kewenangan perusahaan yang tidak jelas/ tegas dalam ikut mengamankan kawasan konservasi di sekitarnya serta pihak berwenang tidak mendukung atau mendorong perusahaan agar

28 Ibid. 
dapat berperan serta dalam pengamanan kawasan konservasi. Kedua, perusahaan yang menyebarkan informasi tentang operasional perusahaan melalui berbagai media umum memberi gambaran yang positif. Namun gambaran ini tidak mencerminkan sepenuhnya pelaksanaan di lapangan atau kesulitan yang dialami dalam melaksanakan tanggung jawab sosial perusahaan. Salah satu masalah yang dihadapi dalam hal ini adalah sumber informasi satu-satunya sebagian pihak terbatas pada informasi resmi perusahaan. Sebagian pihak yang lebih mengetahui kondisi riil tidak dapat menyalurkan informasi ini pada media umum. Ketiga, pada saat terjadi masalah, perusahaan induk dan kontraktornya saling lempar tanggung jawab. Maka muncul pertanyaan siapa yang sebenarnya bertanggung jawab? Bagaimana menilai apakah tuntutan pihak lain terhadap perusahaan (atau organisasi lain) itu sesuai atau berlebihan? Apa yang menjadi tolok ukur yang bisa diterima semua pihak, misalnya untuk menjaga baku mutu lingkungan digunakan tolok ukur yang dapat diukur secara jelas meski belum tentu dipahami atau diterima oleh masyarakat. Keempat, kadang-kadang setelah perusahaan mendapatkan penghargaan, semangat untuk mempertahankan prestasi menurun, sedangkan pihak yang memberi penghargaan tidak melakukan evaluasi lanjutan untuk menilai apakah si penerima penghargaan bisa tetap mempertahankan prestasinya.

Beberapa dampak ketika prinsip tanggung gugat tidak diterapkan antara lain: ${ }^{29}$ Pertama, merugikan pihak lain. Perusahaan, apabila tidak bertanggung gugat atas seluruh operasi, bisa terjadi perusahaan memperoleh keuntungan besar, sedangkan dampak negatif dari operasi yang tidak bertanggung gugat terasa oleh dan di bebankan kepada pihak lain, misalnya penggalian batu bara yang ceroboh menyebabkan tercemarnya air bersih yang dibutuhkan masyarakat sekitar.

Kedua, operasional perusahaan terganggu. Perusahaan, apabila kurang bertanggung gugat, kemungkinan besar pada suatu ketika pihak lain akan menuntut mereka untuk lebih ber- tanggung gugat. Tuntutan ini bisa dengan berbagai cara, termasuk yang mengganggu operasional perusahaan atau berdampak negatif pada citranya, seperti pencemaran sumber air oleh kegiatan perusahaan sering mengakibatkan masyarakat terkena dampaknya melakukan demonstrasi dengan menghentikan seluruh kegiatan perusahaan untuk menuntut perbaikan mutu lingkungan.

Ketiga, kepercayaan pihak lain (investor dan/ atau masyarakat) terhadap perusahaan menurun. Perusahaan, apabila di salah satu bagiannya terdapat tindakan yang kurang bertanggung gugat, dapat mengakibatkan pihak lain berasumsi bahwa secara keseluruhan perusahaan kurang bertanggung jawab. Kepercayaan investor yang menurun, dan ketika masyarakat kurang percaya pada suatu perusahaan, penjualan produk atau jasa bisa menurun.

Keempat, pihak lain tidak turut bertanggung gugat, sehingga sulit untuk mendorong perusahaan beroperasi lebih baik. Pemerintah yang tidak menjalankan fungsi sebagaimana mestinya (kurang/tidak bertanggung gugat), akan lemah posisinya pada saat harus menuntut tanggung jawab pihak lain.

Beberapa cara menerapkan prinsip tanggung gugat antara lain: ${ }^{30}$ Pertama, pemantauan pelaksanaan tanggung jawab sosial perusahaan. Salah satu pendekatan yang dapat dikembangkan adalah pemantauan program tanggung jawab sosial perusahaan secara partisipatif. Pihak yang berkepentingan langsung (perusahaan, pemerintah setempat dan masyarakat setempat) bersama-sama mengembangkan tujuan program tanggung jawab sosial perusahaan, indikator yang hendak dipakai dan mekanisme pelaksanaan pemantauan. Pemantauan partisipatif secara teratur dapat mengurangi tuntutan berkelebihan terhadap program tanggung jawab sosial perusahaan dan lebih menjamin pelaksanaan tanggung jawab sosial perusahaan yang efektif dan efisien.

Kedua, keterlibatan pihak independen. Hal ini dapat dilakukan dengan secara berkala mengundang pihak independen (dengan reputasi 
baik) untuk melakukan evaluasi terhadap sebagian atau seluruh program tanggung jawab sosial perusahaan. Penilaian keberhasilan oleh pihak yang independen dapat meningkatkan kepercayaan pihak lain tentang kesungguhan perusahaan dalam menjalankan tanggung jawab sosial perusahaan. Keuntungan lainnya adalah bahwa evaluasi ini dapat memberikan masukan/ kritikan yang membangun kepada perusahaan karena masyarakat dan pihak lain di luar perusahaan kemungkinan tidak sungkan memberikan pendapat kepada pihak yang dianggap tidak punya kepentingan terhadap atau hubungan dengan perusahaan. Pendekatan ini dapat dilaksanakan dengan baik dan diperlukan pemahaman tentang tanggung jawab sosial perusahaan dari semua pihak, bukan hanya di pihak perusahaan. Ini berkaitan dengan pertanyaan siapa akan memilih pihak ketiga untuk ikut terlibat, bagaimana menanggung biaya keterlibatan pihak ketiga dan penerimaan hasil pihak ketiga. Misalnya, kajian menunjukkan perusahaan cukup bertanggung gugat, namun ada pihak lain yang tidak turut bertanggung gugat. Apakah pihak lain itu siap untuk introspeksi dan melakukan perbaikan sebagai bukti tanggung jawabnya, atau lebih memilih untuk tetap menyalahkan perusahaan?

Ketiga, satu standar untuk perusahaan induk dan kontraktor. Hal ini dilakukan agar tidak terjadi saling melempar tanggung jawab. Perusahaan induk tidak cukup mengembangkan tanggung jawab sosial perusahaan hanya di dalam perusahaan sendiri, namun sejak awal sebaiknya mendorong perusahaan kontraktornya untuk mengikuti standar yang sama dan bertanggung jawab atas penerapan tanggung jawab sosial perusahaan di perusahaannya. Keempat, penyebaran informasi tentang program tanggung jawab sosial perusahaan. Perusahaan induk dapat menyebarluaskan informasi tentang standar yang diterapkan dan standar tersebut juga berlaku bagi kontraktornya untuk mendorong kontraktor menggunakan standar yang sama.

Kelima, akuntabilitas dalam penyebaran informasi. Penyebaran informasi tentang pelaksanaan tanggung jawab sosial di suatu perusahaan harus dilakukan secara bertanggung jawab pula, sesuai kenyataan dan dengan menjelaskan baik hal positif maupun negatifnya. Hal ini akan meningkatkan kepercayaan pihak lain terhadap informasi yang disampaikan dan mengurangi kesalahpahaman.

Keenam, mendorong pihak lain untuk turut bertanggung gugat. Kepentingan terhadap lingkungan alam merupakan kepentingan umum, dan tidak cukup hanya perusahaan yang bertanggung gugat atas dampaknya terhadap lingkungan hidup. Semua pihak, baik pemerintah maupun masyarakat harus ikut mengambil peran dalam menjaga lingkungan hidup. Perusahaan dapat menjadi pelopor dalam kegiatan lingkungan, tidak hanya pada operasinya tetapi juga dengan mengajak kom-ponen masyarakat madani lain untuk melakukan tindakan nyata untuk menjaga dan memperbaiki lingkungan hidupnya.

\section{Penutup \\ Simpulan}

Penerapan prinsip tanggung gugat dalam pelaksanaan tanggung jawab sosial perusahaan dalam rangka implementasi triple bottom line di Indonesia belum menggunakan standar dan parameter yang jelas dan objektif, karena belum mengakomodasi kepentingan para stakeholder secara seimbang, yaitu kepentingan perusahaan/ penanam modal, kepentingan pemerintah dan kepentingan masyarakat sekitar. Standar dan parameter yang digunakan selama ini lebih banyak menguntungkan pihak perusahaan dalam meng-ambil keuntungan yang sebesar-besarnya dari beroperasinya perusahaan. Penerapan prinsip tanggung gugat ini masih dirasa sulit karena belum ada aturan hukum yang jelas.

\section{Saran}

Pemerintah perlu terus membuat standarstandar atau kriteria-kriteria yang jelas dan terukur dalam menerapkan prinsip tanggung gugat pada pelaksanaan tanggung jawab sosial perusahaan. Selain itu, dibutuhkan konsistensi dan komitmen baik dari semua kalangan yaitu pemerintah pelaku usaha (investor) dan masyarakat dalam melaksanakan prinsip tanggung gugat sebagai implementasi dari tanggung jawab sosial perusahaan. 


\section{Daftar Pustaka}

Abbott W.F. and R.J. Monsen. "On the Measurement of Corporate Social Responsibility". Academy of Management J ournal, Vol. 22, No. 3, 2007;

Andersson C.L. and R.L. Bieniaszewska. "The Role of Corporate Social Responsibility in An Oil Company's Expansion Into New Territories". Corporate Social Responsibility and Environmental Management, Vol. 12, No. 1, 2008;

Bansal, P. and T. Hunter, "Strategic Explanations for the Early Adoption of ISO 14001". J ournal of Business Ethics, Vol. 46, No. 3, 2008;

Belal, A.R.; N.A. Khan, and S.A. Alam, "Industrial Pollution and the Environment in Bangladesh: An Overview". Asian J ournal of Environmental Management, Vol. 6, No. 2, 2008;

Berg N. and D. Holtbrugge. "Public Affairs Management Activities of German Multinational Corporations in India". Journal of Business Ethics, Vol. 30, 2009;

Chapple, W.and J. Moon. "Corporate Social Responsibility (CSR) in Asia: A Seven Country Study of CSR Web Site Reporting". Business \& Society, Vol. 44, No. 4, 2005;

Crawford, J. "Responsibility to the International Community As a Whole". 8 Indiana J ournal of Global Legal Studies (INJ GLS) 2007;

Deva, Surya. "Sustainable Good Governance and Corpo-ration: An Analysis of Asymmetries". Georgetown International Environmental Law Review, Summer 2006;

Elkington, J ohn. 2005. Cannibals with Forks, The Triple Bottom Line of Twentieth Century Business, dikutip dari Teguh Sri Pembudi, Corporate Social Responsibility. Sebuah Keharusan dalam Investasi Sosial, Pusat Penyuluhan Sosial (PUSENSOS) Departemen Sosial RI, Jakarta: La Tofi Enterprise;
Herrnstadt, Owen E. "Are International Framework Agreements a Path to Corporate Social Responsibility". University of Pennsylvania J ournal of Business and Employment Law, Fall 2007;

Korhonen, J. "On the Ethics of Social Responsibility-Considering the Paradigm of Industrial Metabolism". Journal of Business Ethics. Vol. 48, 2008;

Krackhardt, Oliver. "Beyond the Neem Tree Conflict: Questions of Corporate Behaviour in a Globalised World". 21 New Zealand University Law Review 347, J une 2005;

Limberg, Godwin. dkk, Bukan Hanya Laba Prinsip-prinsip Bagi Perusahaan Untuk Melaksanakan Tanggung Jawab Sosial, Bogor: Center for Forestry Reseach (CIFOR);

Monsma, David. "Equal Rights, Governance, and the Environment: Integrating Environment Justice Principles in Corporate Social Responsibility". Ecology Law Quarterly, 2006;

Paine, L. "Managing for Organisational Integrity", Harvard Business Review, Vol. 72 No. 2, 2010;

Park Niloufar A. and Carmen M. Butler. "Mayday Payday: Can Corporate Social Responsibility Save Payday Lenders". Rutgers J ournal of Law \& Urban Policy, Fall, 2005;

Suprapto, Siti Adipringadi Adiwoso. "Pola Tanggung Jawab Sosial Perusahaan Lokal di Jakarta". Galang, Vol. 1 No. 2, J anuari 2006;

Tanudjaja, Bing Bedjo. "Perkembangan Corporate Social Responsibilty di Indonesia". J urnal Nirmana, Vol. 8 No. 2 J uli 2006;

Zamagni, Stefano. and Henry Schawalbenberg. "Religious Values and Corporate Decision Making: An Economist's Perspective". Fordham J ournal of Corporate and Financial Law, 2006. 